\title{
Absence of BRAF mutation in pheochromocytoma and paraganglioma
}

\author{
T. VOSECKA ${ }^{1}$, A. VICHA ${ }^{1}$, T. ZELINKA ${ }^{2}$, P. JENCOVA ${ }^{1}$, K. PACAK ${ }^{3}$, J. DUSKOVA ${ }^{4}$, J. BENES ${ }^{5,6}$, A. GUHA ${ }^{7}$, L. STANEK ${ }^{8}$, M. KOHOUTOVA $^{7}$, Z. MUSIL $^{1,7, *}$
}

${ }^{1}$ Department of Pediatric Hematology and Oncology, $2^{\text {nd }}$ Medical School, Charles University and University Hospital Motol, Prague, Czech Republic; ${ }^{2} 3 r d$ Department of Medicine-Department of Endocrinology and Metabolism, First Faculty of Medicine, Charles University in Prague and General University Hospital in Prague; ${ }^{3}$ Section on Medical Neuroendocrinology, Eunice Kennedy Shriver National Institute of Child Health \& Human Development (NICHD), National Institutes of Health, Bethesda, Maryland, 20892, USA; ${ }^{4}$ Institute of Pathology, First Faculty of Medicine, Charles University in Prague and General University Hospital in Prague; ${ }^{5}$ Department of Radiology, 1 st Faculty of Medicine, Charles University in Prague and General University Hospital in Prague; ${ }^{6}$ Institute of Anatomy, 1st Faculty of Medicine, Charles University in Prague; ' Institute of Biology and Medical Genetics, First Faculty of Medicine, Charles University in Prague and General University Hospital in Prague; ${ }^{8}$ Department of Oncology, First Faculty of Medicine, Charles University in Prague and General University Hospital in Prague

${ }^{*}$ Correspondence: musil.z@seznam.cz

Received May 10, 2016 / Accepted October 4, 2016

Pheochromocytomas and Paragangliomas (PHEO/PARA) are rare endocrine tumors originating from the adrenal medulla. More than 20 genes are involved in the tumorigenesis of these tumors, but a substantial part of the causative genetic events remains unexplained. A recent study has reported the presence of the activating BRAF V600E mutation in PCC, suggesting a role for BRAF activation in tumor development. Other studies have not find this mutation. This study investigates the occurrence of the BRAF V600E mutation in these tumors.

A cohort of 64 PHEO/PARA were screened for the BRAF V600E mutation using direct Sanger sequencing and QRT-PCR. All cases investigated displayed wild-type without V600E BRAF mutation

Taken together with all previously screened tumors up to date, only 1 V600E BRAF mutation has been found among 427 PCCs. These findings imply that the V600E BRAF mutation is a rare event in PHEO/PARA.

Key words: pheochromocytoma, paraganglioma, BRAF, mutation

$\mathrm{B}-\mathrm{Raf}$ is a protein produced by the human gene $B R A F$ $[1,2]$. B-Raf is a 766-amino acid protein composed of three conserved domains characteristics of the Raf kinase family. In active conformation, B-Raf forms dimers via electrostatic interactions of its kinase domains and hydrogen-bonding [3]. Cell growth is directed by signalling from the B-Raf protein, since it is a member of the Raf kinase family of growth signal transduction protein kinases. Hence, it plays a role in regulating the MAP kinase/ERKs signalling pathway, which in turn affects cell division, differentiation, and secretion. Human cancers have been associated with more than 30 mutations of the BRAF. In $90 \%$ of these cases, thymine is substituted with adenine at nucleotide 1799 (p. V600E) [4].

The frequency of $B R A F$ mutations varies widely in human cancers. Higher frequencies are found in melanomas and nevi, hairy cell leukaemia, and Langerhans cell histiocytosis while rarely in other tumors such as non-Hodgkins lym- phoma, colorectal cancer, astrocytoma, papillary thyroid carcinoma, non-small-cell lung carcinoma, lung adenocarcinoma, and neuroblastoma [5-13]. Furthermore, a high frequency of $B R A F \mathrm{~V} 600 \mathrm{E}$ mutations have been detected in ameloblastoma, a locally infiltrative odontogenic benign neoplasm [14].

To date, only one study has identified a $B R A F$ mutation with an incidence of $1,2 \%(1 / 85)$ in pheochromocytoma and paraganglioma (PHEO/PGL) [15]. Paulson et al, summarized data from other studies and did not found V600E BRAF mutation in $0,3 \%(1 / 336)$ PHEO/PGL tumors $[16,17]$.

Similary to neuroblastoma which have incidence of $B R A F$ mutation about 1\%, PHEO is also tumor of the adrenal gland that arises from chromaffin cells located in the adrenal medulla. PGL arise from extra-adrenal chromaffin cells located in sympathetic (abdomen, pelvis) or parasympathetic (head and neck) ganglions $[18,19]$. These tumors may produce and 
secrete catecholamines and metanephrines [20-22]. Currently, there are about 20 known genes associated with PHEO/PGL pathogenesis [18, 23-25].

Here, we aimed to assess the presence of the BRAF mutation on a large population of PHEOs/PGLs and to further contribute to controversial view whether this mutation may or may not occur in these tumors $[18,26]$. Since $B R A F$ mutation is a very good treatment target, the presence of this mutation in some of these tumors could result in the use of B Raf inhibitors of metastatic forms for which there has not been effective treatment so far.

\section{Materials and methods}

Our study included 64 patients with PHEO/PGLs (32 men and 32 women, range from 7 to 77 years). Patient's samples were collected from the $3^{\text {rd }}$ Department of Medicine, $1^{\text {st }}$ Faculty of Medicine, Faculty Hospital and Department of Pediatric Hematology and Oncology, $2^{\text {nd }}$ Faculty of Medicine, Prague, Czech Republic. The informed consent was obtained from all involved patients. Clinical characteristics of study objects are described in Table 1.

Table 1. Clinical and germline mutations characterization

\begin{tabular}{|c|c|c|c|c|c|c|c|c|}
\hline Num. & $\begin{array}{l}\text { Age } \\
(y)\end{array}$ & sex & $\begin{array}{l}\mathrm{PHEO} / \\
\text { PARA }\end{array}$ & site & Volum (ml) & Metastases & Familiar & Germline mutation of SDHB, SDHD, RET, VHL genes \\
\hline 1 & 36 & $\mathrm{~F}$ & PHEO & Left & 39 & No & No & Neg. \\
\hline 2 & 16 & M & PHEO & Right & n.d. & No & No & Neg. \\
\hline 3 & 12 & $\mathrm{~F}$ & PHEO & Bilateral & n.d. & No & No & VHL: c.602T>C, p.Leu201Pro \\
\hline 4 & 65 & $\mathrm{~F}$ & PHEO & Right & 45 & no & No & Neg. $\quad$ \\
\hline 5 & 45 & $\mathrm{~F}$ & PARA & Retroperitoneum & 31 & no & No & Neg. \\
\hline 6 & 13 & $\mathrm{~F}$ & PARA & Retroperitoneum & n.d. & no & No & $\begin{array}{l}\text { SDHB: c. } 589-600 \text { dup. AGC ACC AGC TGC, p. Cys } \\
196 \text { dup. Ser } 197 \text { Thr } 198 \text { Ser } 199 \text { Cys } 201\end{array}$ \\
\hline 7 & 68 & M & PHEO & Right & 70 & no & No & Neg. \\
\hline 8 & 35 & $\mathrm{~F}$ & PHEO & Left & 120 & no & No & Neg. \\
\hline 9 & 62 & $\mathrm{~F}$ & PHEO & Right & 70 & no & No & Neg. \\
\hline 10 & 7 & M & PARA & Mediastinum & 24 & no & No & VHL: c.376G>A, p.Asp126Asn \\
\hline 11 & 64 & $\mathrm{~F}$ & PHEO & Left & 42 & no & No & Neg. \\
\hline 12 & 14 & M & PHEO & Right & n.d. & no & No & Neg. \\
\hline 13 & 22 & $\mathrm{~F}$ & PHEO & Left & 46 & no & No & Neg. \\
\hline 14 & 35 & M & PHEO & Left & 80 & no & No & Neg. \\
\hline 15 & 31 & $\mathrm{~F}$ & PHEO & Bilateral & $10 ; 30$ & no & No & RET: c.1901G>C, p.Cys634Ser; c.1921G>T, p.Ala641Ser \\
\hline 16 & 52 & M & PHEO & Bilateral & 6; hyperplasia & no & No & Neg. \\
\hline 17 & 59 & $\mathrm{~F}$ & PHEO & Left & 63 & no & No & Neg. \\
\hline 18 & 68 & M & PHEO & Left & 28 & no & No & Neg. \\
\hline 19 & 60 & M & PHEO & Right & 13 & no & No & Neg. \\
\hline 20 & 15 & M & PHEO & Right & n.d. & no & No & Neg. \\
\hline 21 & 73 & $\mathrm{~F}$ & PHEO & Right & 35 & no & No & Neg. \\
\hline 22 & 31 & F & PARA & Middle ear & n.d. & no & No & Neg. \\
\hline 23 & 27 & $\mathrm{~F}$ & PARA & Retroperitoneum & 60 & no & No & Neg. \\
\hline 24 & 41 & M & PHEO & Left & 100 & no & No & n.d. \\
\hline 25 & 76 & M & PHEO & Right & 60 & no & No & Neg. \\
\hline 26 & 23 & M & PARA & Mediastinum & 60 & bone; GC; neck & Yes & Neg. \\
\hline 27 & 47 & M & PHEO & Left & 58 & no & No & Neg. \\
\hline 28 & 13 & M & PARA & Rertoperitoneum & $86+80$ & no & No & Neg. \\
\hline 29 & 26 & M & PARA & Retroperitoneum & 35 & no & No & SDHD: c.361C>T, p.Gln121X \\
\hline 30 & 65 & $\mathrm{~F}$ & PHEO & Right & 50 & no & No & Neg. \\
\hline 31 & 40 & M & PHEO & Bilateral & $30 ; 14$ & no & No & Neg. \\
\hline 32 & 40 & M & PHEO & Right & 70 & no & No & Neg. \\
\hline 33 & 68 & $\mathrm{~F}$ & PHEO & Right & 80 & no & No & Neg. \\
\hline 34 & 67 & $\mathrm{~F}$ & PHEO & Right & 60 & no & No & Neg. \\
\hline 35 & 77 & $\mathrm{~F}$ & PHEO & Right & 65 & no & No & Neg. \\
\hline 36 & 26 & $\mathrm{~F}$ & PHEO & Left & 50 & no & No & Neg. \\
\hline 37 & 20 & M & PHEO & Bilateral & $70 ; 40$ & no & No & VHL: c. $340+2 \mathrm{~T}>\mathrm{C}$ \\
\hline 38 & 34 & M & PHEO & Right & 35 & no & No & Neg. \\
\hline 39 & 27 & M & PARA & Neck & n.d. & no & No & SDHD: c.2T>A, p.Met1Lys \\
\hline
\end{tabular}


Table 1. Clinical and germline mutations characterization (continued)

\begin{tabular}{|c|c|c|c|c|c|c|c|c|}
\hline Num. & $\begin{array}{l}\text { Age } \\
(y)\end{array}$ & $\operatorname{sex}$ & $\begin{array}{l}\text { PHEO/ } \\
\text { PARA }\end{array}$ & site & Volum (ml) & Metastases & Familiar & Germline mutation of SDHB, SDHD, RET, VHL genes \\
\hline 40 & 65 & $\mathrm{~F}$ & PHEO & Left & 17 & no & No & Neg. \\
\hline 41 & 15 & $\mathrm{~F}$ & PHEO & Left & n.d. & no & No & Neg. \\
\hline 42 & 24 & M & PHEO & Bilateral & $30 ; 6,9$ & no & No & VHL: c.374A>C, p.His125Pro \\
\hline 43 & 47 & M & PHEO & Right & 55 & no & No & Neg. \\
\hline 44 & 60 & $\mathrm{~F}$ & PHEO & Left & 665 & no & No & Neg. \\
\hline 45 & 42 & M & PHEO & Right & 12 & $\begin{array}{l}\text { liver; bone;lymph } \\
\text { nodes; lung }\end{array}$ & No & Neg. \\
\hline 46 & 75 & $\mathrm{~F}$ & PARA & Pelvis & 50 & no & No & Neg. \\
\hline 47 & 64 & $\mathrm{~F}$ & PHEO & Left & 38 & no & No & Neg. \\
\hline 48 & 60 & $\mathrm{~F}$ & PHEO & Bilateral & 30;hyperplasia & no & No & Neg. \\
\hline 49 & 61 & $\mathrm{M}$ & PHEO & Left & 95 & no & No & Neg. \\
\hline 50 & 33 & $\mathrm{~F}$ & PHEO & Right & 55 & no & No & Neg. \\
\hline 51 & 57 & $\mathrm{~F}$ & PHEO & Left & 60 & no & No & VHL: c.351G>A, p.Trp117Ter \\
\hline 52 & 21 & M & PHEO & Bilateral & $60 ; 25$ & no & No & Neg. \\
\hline 53 & 50 & M & PHEO & Right & 8 & no & No & Neg. \\
\hline 54 & 28 & $\mathrm{~F}$ & PHEO & Left & 55 & no & No & Neg. \\
\hline 55 & 61 & $\mathrm{~F}$ & PHEO & Right & 60 & no & No & Neg. \\
\hline 56 & 51 & M & PHEO & Right & 50 & no & No & Neg. \\
\hline 57 & 9 & $\mathrm{~F}$ & & Retroperitoneum & 360 & no & No & Neg. \\
\hline 58 & 68 & M & PHEO & Left & 40 & no & No & Neg. \\
\hline 59 & 14 & $\mathrm{~F}$ & & Retroperitoneum & n.d. & no & No & n.d. \\
\hline 60 & 77 & M & PHEO & Left & 90 & no & No & Neg. \\
\hline 61 & 66 & M & PHEO & Right & 55 & no & No & Neg. \\
\hline 62 & 74 & $\mathrm{~F}$ & & Zuckerkandel & 27 & no & No & Neg. \\
\hline 63 & 59 & M & PHEO & Left & 80 & no & No & n.d. \\
\hline 64 & 59 & $\mathrm{~F}$ & PHEO & Left & 110 & no & No & Neg. \\
\hline
\end{tabular}

Table1. characterized clinical data and germline mutation status of SDHB, SDHD, VHL and RET genes.

PHEO/PARA-Pheochromocytoma/Paraganglioma; neg.- negative; n.d.- not done, M-male; F- female; GC-glomus caroticum

Genomic DNA was extracted from fresh or frozen peripheral blood using QIAamp DNA Mini Kit (Qiagene, USA). Somatic DNA was extracted from frozen tumour's samples after histological confirmation of PHEO/PGL. DNA was extracted by Puregene Core kit A (Qiagene, USA). Quality of DNA was checked by NanoDrop ${ }^{\mathrm{ma}} 2000 / 2000$ c Spectrophotometers (ThermoScientific)

Sanger sequencing. PCR primers for $B R A F$ gene have been designed based on GenBank sequences using the Primer 3 software including intron-exon boundaries, reverse primer 5' - CTGTTCAAACTGATGGGACCC- 3', forward primer $5^{\prime}$ - TGCTTGCTCTGATAGGAAAATG$3^{\prime}$. The BRAF PCR conditions are as follows $25 \mu$ reaction mixture contained 1x PCR buffer (Fermentas), between 50-300 ng of genomic DNA as template, $1.5 \mathrm{mM} \mathrm{MgCl} 2$ (Fermentas), $25 \mathrm{pmol}$ of each primer, $200 \mu \mathrm{M}$ of each deoxynucleotide triphosphate (Fermentas), and 1.0 unit of TaqDNA polymerase (MBI Fermentas). Amplification conditions were included an initial denaturation at $94 \mathrm{C}^{\circ}$ for $3 \mathrm{~min}$., followed by 35 cycles of $45 \mathrm{sec}$ at $94 \mathrm{C}^{\circ}, 45 \mathrm{sec}$ at $60 \mathrm{C}^{\circ}, 1 \mathrm{~min}$. at $72 \mathrm{C}^{\circ}$ and final extension step running $5 \mathrm{~min}$. at $72 \mathrm{C}^{\circ}$. DNA fragments were sequenced in both directions using an automatic fluorescent ABI PrismTM 3130 Genetic Analyzer (PE Applied Biosystems) according to the manufacturer's instructions.

QRT-PCR for detection of V600E BRAF mutation. PCR primers and probes (accession No. NG_007873), PCR conditions and results classification were designed by Lang et al. [27]. These primers and probes are targeted against each mutation, and a mutation-unspecific region was used as a reference amplicon. All unlabelled primers were synthesized by EastPort Praha, Czech Republic; and probes (TaqMan) were purchased from Applied Biosystems, Foster City, CA. Real-Time PCR Reference PCR was performed in a $25 \mu \mathrm{l}$ reaction volume with HotstarTaq DNA polymerase, Qiagene, $900 \mathrm{nmol} / \mathrm{L}$ of each BRAF mutation-un-specific primer, 100 $\mathrm{nmol} / \mathrm{L}$ of the BRAF probe, $112.5 \mathrm{nmol} / \mathrm{L}$ of each internal control primer, $25 \mathrm{nmol} / \mathrm{L}$ of internal control probe, and 5 $\mu \mathrm{l}$ of DNA of varying concentration. Allele-specific PCRs were performed according to the same protocol but using a concentration of $450 \mathrm{nmol} / \mathrm{L}$ of allele-specific primer. All real-time PCRs were performed on a system (TaqMan 7300 PCR System Applied Biosystems, Foster City, CA) under the following thermocycling conditions: $95^{\circ} \mathrm{C}$ for 10 minutes, 
followed by 50 cycles of $90^{\circ} \mathrm{C}$ for 15 seconds and $60^{\circ} \mathrm{C}$ for 1 minute. Cycle threshold $(\mathrm{Ct})$ values were recorded for reference PCR and for each allele-specific PCR, and corresponding $\Delta \mathrm{Ct}$ values (ie, allele-specific $\mathrm{Ct}$ minus reference $\mathrm{Ct})$ were calculated.

\section{Results}

Somatic activating BRAF mutations in exon 15 were investigated in 64 tumor samples. Initially, we used Sanger sequencing. Results for V600E BRAF mutation were validated by QRT-PCR. All of these samples were negative for $B R A F$ mutation in exon 15.

\section{Discussion}

In the present study, which included 66 PHEOs/PGL, we did not confirm the presence of any BRAF mutations. This contrasts Luchetti et al., who detected V600E BRAF mutation in $1,2 \%(1 / 85)$ of these tumors. Until now, 427 PHEOs/ PGLs were investigated for the presence of a BRAF mutation, which was only found ] in 1 of these tumors, suggesting that the BRAF V600E mutation is a extremely rare genetic event in $\mathrm{PHEO} / \mathrm{PGL}$ and would not serve as a target for new treatment options in metastatic PHEO/PGL.

Previous studies have demonstrated that tumor oncogene activation such as RET, HIF2A, and HRAS in PHEO/PGL may result in tumorigenesis of these tumors [15, 24, 26, 28, 29]. Furthermore, additional gene expression studies suggested that most PHEO/PGLs can be classified into two distinct groups (cluster1 and cluster 2) by transcription profiling: cluster 1 includes tumors that harbour mutations in genes linked to pseudohypoxia (VHL, HIF2A, SDHA, SDHB, SDHC, and $S D H D$ ) and cluster 2 contains tumors harbouring mutations in genes that are involved in the kinase signalling characterized by the activation of the PIK3/AKT/mTOR and RAS/RAF/ ERK pathways (RET, NF1, TMEM127, MAX, and HRAS), both converging on the HIF-signaling pathway [30]. The protooncogene RET is a tyrosine kinase receptor primarily expressed in the neural crest cells. RET mutations have been associated with increased activation of PI3K/v-Akt signals. NF1 encodes for the neurofibromin protein, a GTPase- activating protein in the RAS signaling cascade and mTOR signaling pathway. Thus, RET and NF1 mutations lead to activation of the PI3K/ AKT/mTOR and RAS/RAF/MAPK signaling pathways [24]. Thus, RAS/RAF/MAPK signaling pathways genes are a promising aim of mutations in PHEO/PGL. That supposition was confirmed by Luchetti et al. and other which found somatic HRAS mutation in PHEO/PGL $[26,15]$ very recently Luchetti et al. found V600E BRAF mutation in 1,2\% (1/85 cases). We investigated 64 cases without any detection of the V600E $B R A F$ mutation.

In conclusion, our results along with previous results, suggest that the BRAF V600E mutation is an extremely rare genetic event in PHEO/PGL.
Acknowledgements: Study was supported by Ministry of Education of the Czech Republic PRVOUK-P27/LF1/1, PRVOUK P35/ LF1/5, SVV 260257/2016, Ministry of Health, Czech Republic- conceptual development of research organization, University Hospital Motol, Prague,Czech Republic 00064203

\section{References}

[1] SITHANANDAM G, DRUCK T, CANNIZZARO LA, LEUZZI G, HUEBNER K et al. B-raf and a B-raf pseudogene are located on 7q in man. Oncogene 1992; 7: 795-799.

[2] SITHANANDAM G, KOLCH W, DUH FM, RAPP UR Complete coding sequence of a human B-raf cDNA and detection of B-raf protein kinase with isozyme specific antibodies. Oncogene 1990; 5: 1775-1780.

[3] BOLLAG G, TSAI J, ZHANG J, ZHANG C, IBRAHIM P et al. Vemurafenib: the first drug approved for BRAF-mutant cancer. Nature reviews Drug discovery 2012; 11: 873-886. https://doi.org/10.1038/nrd3847

[4] TAN YH, LIU Y, EU KW, ANG PW, LI WQ et al. Detection of BRAF V600E mutation by pyrosequencing. Pathology 2008; 40: 295-298. https://doi.org/10.1080/00313020801911512

[5] NAMBA H, NAKASHIMA M, HAYASHI T, HAYASHIDA N, MAEDA S et al. Clinical implication of hot spot BRAF mutation, V599E, in papillary thyroid cancers. J Clin Endocrinol Metab 2003; 88: 4393-4397. https://doi.org/10.1210/jc.2003-030305

[6] SHUKLA N, AMEUR N, YILMAZ I, NAFA K, LAU CY et al. Oncogene mutation profiling of pediatric solid tumors reveals significant subsets of embryonal rhabdomyosarcoma and neuroblastoma with mutated genes in growth signaling pathways. Clin Cancer Res 2012; 18: 748-757. https://doi. org/10.1158/1078-0432.CCR-11-2056

[7] AHMADZADEH A, SHAHRABI S, JASEB K, NOROZI F, SHAHJAHANI M et al. BRAF Mutation in Hairy Cell Leukemia. Oncology reviews 2014; 8: 253. https://doi.org/10.4081/ oncol.2014.253

[8] EL DEMELLAWY D, YOUNG JL, DE NANASSY J, CHERNETSOVA E, NASR A Langerhans cell histiocytosis: a comprehensive review. Pathology 2015; 47: 294-301. https:// doi.org/10.1097/PAT.0000000000000256

[9] JOHNSON DB, SOSMAN JA Therapeutic Advances and Treatment Options in Metastatic Melanoma. JAMA oncology 2015; 1: 380-386. https://doi.org/10.1001/ jamaoncol.2015.0565

[10] GAUTSCHI O, MILIA J, CABARROU B, BLUTHGEN MV, BESSE B et al. Targeted Therapy for Patients with BRAFMutant Lung Cancer: Results from the European EURAF Cohort. Journal of thoracic oncology : official publication of the International Association for the Study of Lung Cancer 2015.

[11] DE GROOT JF High-grade gliomas. Continuum 2015; 21: 332-344.

[12] THEELER BJ, ELLEZAM B, MELGUIZO-GAVILANES I, DE GROOT JF, MAHAJAN A et al. Adult brainstem gliomas: Correlation of clinical and molecular features. Journal of the neurological sciences 2015; 353: 92-97. https://doi. org/10.1016/j.jns.2015.04.014 
[13] SORBYE H, DRAGOMIR A, SUNDSTROM M, PFEIFFER P, THUNBERG $U$ et al. High BRAF Mutation Frequency and Marked Survival Differences in Subgroups According to KRAS/BRAF Mutation Status and Tumor Tissue Availability in a Prospective Population-Based Metastatic Colorectal Cancer Cohort. PLoS One 2015; 10:e0131046. https://doi. org/10.1371/journal.pone.0131046

[14] KURPPA KJ, CATON J, MORGAN PR, RISTIMAKI A, RUHIN B et al. High frequency of BRAF V600E mutations in ameloblastoma. The Journal of pathology 2014; 232: 492-498. https://doi.org/10.1002/path.4317

[15] LUCHETTI A, WALSH D, RODGER F, CLARK G, MARTIN $\mathrm{T}$ et al. Profiling of somatic mutations in phaeochromocytoma and paraganglioma by targeted next generation sequencing analysis. International journal of endocrinology 2015; 2015: 138573. https://doi.org/10.1155/2015/138573

[16] GELI J, KISS N, KARIMI M, LEE JJ, BACKDAHL $M$ et al. Global and regional $\mathrm{CpG}$ methylation in pheochromocytomas and abdominal paragangliomas: association to malignant behavior. Clin Cancer Res 2008; 14: 2551-2559. https://doi. org/10.1158/1078-0432.CCR-07-1867

[17] PAULSSON JO, SVAHN F, WELANDER J, BRUNAUD L, SODERKVIST $P$ et al. Absence of the BRAF V600E mutation in pheochromocytoma. Journal of endocrinological investigation 2015.

[18] MARTUCCI VL, PACAK K Pheochromocytoma and paraganglioma: diagnosis, genetics, management, and treatment. Current problems in cancer 2014; 38: 7-41. https://doi. org/10.1016/j.currproblcancer.2014.01.001

[19] LENDERS JW, DUH QY, EISENHOFER G, GIMENEZROQUEPLO AP, GREBE SK et al. Pheochromocytoma and paraganglioma: an endocrine society clinical practice guideline. J Clin Endocrinol Metab 2014; 99: 1915-1942. https:// doi.org/10.1210/jc.2014-1498

[20] HAVEKES B, PACAK K Pheochromocytoma. Nature clinical practice Cardiovascular medicine 2008; 5:E1. https://doi. org/10.1038/ncpcardio1131

[21] DARR R, LENDERS JW, HOFBAUER LC, NAUMANN B, BORNSTEIN SR et al. Pheochromocytoma- update on disease management. Therapeutic advances in endocrinology and metabolism 2012; 3: 11-26. https://doi. org/10.1177/2042018812437356

[22] EISENHOFER G, LENDERS JW, SIEGERT G, BORNSTEIN SR, FRIBERG $\mathrm{P}$ et al. Plasma methoxytyramine: a novel bi- omarker of metastatic pheochromocytoma and paraganglioma in relation to established risk factors of tumour size, location and SDHB mutation status. Eur J Cancer 2012; 48: 1739-1749. https://doi.org/10.1016/j.ejca.2011.07.016

[23] VICHA A, MERCADO-ASIS LB Pacak-zhuang syndrome: a new kid on the block. Endocrine practice : official journal of the American College of Endocrinology and the American Association of Clinical Endocrinologists 2014; 20: 1234-1235. https://doi.org/10.4158/endp.20.11. g37v757188j41v24

[24] VICHA A, MUSIL Z, PACAK K Genetics of pheochromocytoma and paraganglioma syndromes: new advances and future treatment options. Current opinion in endocrinology, diabetes, and obesity 2013; 20: 186-191. https://doi.org/10.1097/ MED.0b013e $32835 \mathrm{fcc} 45$

[25] VICHA A, TAIEB D, PACAK K Current views on cell metabolism in SDHx-related pheochromocytoma and paraganglioma. Endocr Relat Cancer 2014. https://doi. org/10.1530/ERC-13-0398

[26] CRONA J, DELGADO VERDUGO A, MAHARJAN R, STALBERG P, GRANBERG D et al. Somatic mutations in H-RAS in sporadic pheochromocytoma and paraganglioma identified by exome sequencing. J Clin Endocrinol Metab 2013; 98:E1266-1271. https://doi.org/10.1210/ jc. 2012-4257

[27] LANG AH, DREXEL H, GELLER-RHOMBERG S, STARK N, WINDER T et al. Optimized allele-specific real-time PCR assays for the detection of common mutations in KRAS and BRAF. The Journal of molecular diagnostics : JMD 2011; 13: 23-28. https://doi.org/10.1016/j.jmoldx.2010.11.007

[28] CRONA J, MAHARJAN R, DELGADO VERDUGO A, STALBERG P, GRANBERG D et al. MAX mutations status in Swedish patients with pheochromocytoma and paraganglioma tumours. Familial cancer 2014; 13: 121-125. https:// doi.org/10.1007/s10689-013-9666-3

[29] CRONA J, NORDLING M, MAHARJAN R, GRANBERG D, STALBERG $P$ et al. Integrative genetic characterization and phenotype correlations in pheochromocytoma and paraganglioma tumours. PLoS One 2014; 9:e86756. https:// doi.org/10.1371/journal.pone.0086756

[30] JOCHMANOVA I, YANG C, ZHUANG Z, PACAK K Hypoxia-inducible factor signaling in pheochromocytoma: turning the rudder in the right direction. J Natl Cancer Inst 2013; 105: 1270-1283. https://doi.org/10.1093/jnci/djt201 